\title{
Introduction: James MacGregor Burns and the study of leadership
}

\section{George R. Goethals}

It was altogether fitting and proper that the April 2015 conference celebrating the legacy of James MacGregor Burns, the most important founder of "leadership studies," was held at Mount Vernon, the home of the most important founder of the United States of America. As a biographer of Washington, and others, Burns would have appreciated the appropriateness. At times during the conference it almost felt that Burns was indeed present, appreciating that appropriateness. He had died nine months earlier, and his memory was vivid during our deliberations. The papers and discussions that took place there offered a review of Burns's major conceptual contributions to the study of leadership, a sympathetic critique of those contributions, or extrapolations from them, and their application in understanding leadership in a variety of historical contexts, in particular, the US presidency.

Accordingly, I will highlight some of Burns's most important ideas and then discuss the extensions or qualifications of those ideas, and the use that is made of them, in the chapters included in this volume. I shall also note the influence and reach of Professor Burns's leadership through his mentorship and colleagueship with students, fellow teachers, and scholars devoted to the study of leadership.

\section{THE ESSENTIAL JAMES MACGREGOR BURNS}

Let me begin with my sense of Burns's most important and relevant conceptual contributions. In his 1978 book Leadership, Burns discussed the relationship between power and leadership, and, most importantly, introduced the distinction between "transactional leadership" and "transforming leadership." There are two essential points to Burns's conception of power. First, it is conceived as the capacity of one person to influence another person's behavior by some degree of control over 
outcomes or resources that are valued by that other person. One could speak of one person's capacity to reward or punish another person, given that other person's motives, and therefore to influence that individual's behavior. Second, Burns emphasizes that power exists in a relationship. It is mutual, though often not symmetric. One person may have more power relative to the other party than the other has in return. But both individuals have power. There is a relationship of mutual potential influence. In distinguishing power from leadership, Burns adds another crucial point: that people who wield power, while in a relationship, are ultimately only concerned with their own motives. They use their power to get what they want. They may serve the other person's motives as well, but only as an instrument to satisfy their own desires.

Leadership, in contrast, is also a relationship where both parties have power, but the person initiating leadership is genuinely concerned about the motives of others in the relationship as well, namely, the followers. Leaders "arouse, engage, and satisfy the motives of followers." ${ }^{2}$ The difference between the power-wielder's lack of concern about the motives of others and the leader's deep concern for the motives of followers is one that has profound implications for the way Burns understood leadership. In particular, he noted that "All leaders are actual or potential power-holders, but not all power-holders are leaders." Whether one qualifies as a leader or merely as a power-wielder depends on having true concern for what matters to followers.

Besides the idea of leader-follower mutuality, another crucial element in Burns's conception of leadership is that of conflict. The leader's efforts to engage followers takes place in a context of conflict between the direction offered by one leader and that offered by other potential leaders: "Leadership over human beings is exercised ... in competition or conflict," with other people trying to lead the same individuals. ${ }^{3}$ Burns very much believed in the value of conflict. Out of conflict, values come into focus, and leaders have the potential to achieve moral, transforming change that accords with those values.

Thus conflict relates to what is perhaps the most important influential idea in James MacGregor Burns's corpus of work, the idea of transforming leadership. First, it should be mentioned that Burns's transforming leadership is often mistakenly called "transformational leadership." The two are not the same. Bernard Bass developed a research program on transformational and transactional leadership, and he credits Burns with originating the idea of transformational leadership. ${ }^{4}$ However, the differences between the Burns and Bass concepts are important. Both scholars contrasted their idea of transforming (Burns) or transformational (Bass) 
leadership with essentially equivalent conceptions of transactional leadership. The latter is influence or leadership in which leaders reward or punish-or promise to do so-the behavior of followers in order to influence their attitudes or behavior. For Bass, transformational leadership involves engaging followers to make more effort through being charismatic, giving inspirational speeches, stimulating thought, and showing consideration for individuals. For Burns, the key to transforming leadership is raising followers to higher levels of motivation and morality. He defined it as follows: Transforming "leadership occurs when one or more persons engage with others in such a way that leaders and followers raise one another to higher levels of motivation and morality." three important elements to this definition that point to some of Burns's most important and original ideas: the centrality of followers; the nature of motivation; and the definition of morality.

The crucial role and value of followers is suggested in Burns's distinction, noted above, between power and leadership. The powerwielder is not concerned about the motives or concerns of followers. The leader cares very much. As a result, leaders want to elevate and empower followers in raising them to higher levels of motivation and morality. In fact, Burns argues that the mutual elevation of leaders and followers creates "new cadres of leaders." While this is generally good news, newly elevated leaders then may challenge the original leaders who spurred their elevation. This may create conflict. Even so, for Burns, since conflict clarifies values, that can still be a good thing.

What does Burns mean when he refers to higher levels of motivation? First, I note that there is overlap between that phrase and Bass's emphasis on increased task focus and effort stimulated by transformational leadership. But, further, Burns makes an important distinction between "wants" and "needs." Wants are individual cravings or wishes - the kinds of urges that psychologists would call motives, or drives and needs. However, Burns viewed needs as different from wants, the key distinction being that wants are individual and may focus on gratifications that are not essential. Needs are socially recognized as legitimate demands that groups of followers place on leaders. They are not simply personal, but express the wishes of segments of society. Both wants and needs are motives that leaders must find ways to gratify. The wants of individuals and the needs of society are motives that impinge on the relationship between leaders and followers.

There is another important aspect of Burns's discussion of motivation. In arguing that leaders engage followers in ways that work toward satisfying their motives, he contends that the satisfaction of existing 
motives provides the opportunity for leaders to change motives, transforming them by bringing new social needs to consciousness once existing needs have been gratified. In Burns's view of transforming moral leadership, the new needs and corresponding values that a leader can arouse are directed toward important political goals. The leader engages in "the purposeful awakening of persons into a state of political consciousness." The new political goals or needs that are aroused and defined may have existed in some nonconscious or unexpressed form in followers before they were brought into consciousness. When they are subsequently brought forward they can be powerful forces toward political change.

In emphasizing the idea that transforming leadership makes conscious needs that had only been unconscious, Burns takes an idea of Sigmund Freud and puts it into a new context. One of Freud's most important ideas was that psychological development, and healthy psychological functioning, involved, among other things, making parts of the unconscious, conscious. As Freud famously put it, "Where id was, there ego shall be."7

Burns's claim that transforming leadership changes and elevates motives overlaps considerably with Bass's implication that transformational leadership leads to higher levels of motivation. But Burns's emphasis on transforming leadership elevating morality separates it completely from the concept of transformational leadership. That emphasis is the most distinctive part of Burns's approach to leadership. In his view, leadership is moral, and transforming leadership raises followers to higher levels of morality. This idea permeates all of Burns's work, more or less explicitly. In his 1978 book, Burns entitles his introductory chapter on leadership "The Structure of Moral Leadership." More pointedly, Burns argued in his 2003 book Transforming Leadership that leadership "is not only a descriptive term but a prescriptive one, embracing a moral, even a passionate, dimension ... I contend that there is nothing neutral about leadership; it is valued as a moral necessity."

Burns's focus on leadership, particularly transforming leadership, as being highly moral raises the question of how he conceived morality. $\mathrm{He}$ made distinctions that-like his concepts of transforming leadership, conflict, and need-underline the importance he placed on values. Burns distinguishes three categories of morality. The first is virtue-being chaste, honest, and self-controlled. The second is ethics-integrity, trustworthiness, doing unto others as they do unto you. Third, and most important, are values, particularly "such lofty public principles as order, liberty, equality ... justice, and the pursuit of happiness." ${ }^{\prime 9}$ Burns felt that values trump virtue and ethics, such that Franklin D. Roosevelt can be 
judged as a moral leader given his success in transforming American society in the direction of justice, and enhancing the four freedoms he so eloquently articulated-adding freedom from fear and from want to freedom of religion and of speech. The fact that he had many extramarital affairs (lack of virtue) and lied to his country about what he has doing to help Great Britain before the US entered World War II (a failure of ethics) dims in comparison to the morality of realizing important social values. As we shall see, Burns's perspective on morality has been critiqued by others. However, for him, the realization of fundamental values was the true test of moral leadership.

This point brings us to the ultimate emphasis of Burns's work on purpose, change, and moral elevation directed toward the betterment of society. He stated the idea in different ways in different contexts, but the emphasis was always consistent. Toward the end of his 1978 Leadership, he wrote: "The ultimate test of practical leadership is the realization of intended, real change that meets people's enduring needs." ${ }^{10}$ In Transforming Leadership he said about creative leadership that its "ultimate test" was "not only having a new idea but in bringing it to life, accomplishing the real-world change it promises." ${ }^{11}$ For Burns, leadership was about moral elevation and change.

While I have focused on James MacGregor Burns's conceptual contributions, I must not overlook his distinguished works of biography, history, and government. His prize-winning biographies of Franklin Roosevelt-Roosevelt: The Lion and the Fox and Roosevelt: The Soldier of Freedom - have been enormously influential, as have his studies of George Washington, John F. Kennedy, the Supreme Court, political parties, the US Congress, the Enlightenment, political parties and campaigns, and the American founding. Burns's legacy has been enormous. His scholarly leadership passes his own test of bringing meaningful and enduring change to our understanding of the human condition.

\section{THE PERSONAL LEGACY OF JAMES MACGREGOR BURNS}

As with any leader, it can be difficult to separate the impact and influence of Professor Burns's ideas from the impact that he had as a person. Howard Gardner suggests the connection as he distinguishes the story that a leader relates from the way he or she embodies that story. In Burns's case, we can start with the students he inspired and helped launch into distinguished scholarly careers. They include presidential historian Michael Beschloss and Edward Larson, Pulitzer Prize-winning 
scholar of history, science, religion and law, and countless others. Equally important has been the influence Burns has had through productive collaborations with Jack Peltason and Thomas Cronin, working together on many editions of the classic government textbook Government by the People; and with fellow presidential scholars Georgia Sorenson, in their consideration of Bill Clinton, and Susan Dunn, in their books George Washington and The Three Roosevelts. Beyond these direct collaborations, Burns helped bring constructive change to academia by contributing to the establishment of leadership studies as an interdisciplinary enterprise at the Jepson School of Leadership Studies at the University of Richmond; the James MacGregor Burns Academy of Leadership, originally at the University of Maryland and now at Cambridge University in England; and the Program in Leadership Studies at his alma mater, Williams College.

Importantly for the study leadership, from the very beginning - in his work on American history and government, his studies of Franklin Roosevelt, and his conceptual treatments of leadership-Burns sought to get to the very essence of the phenomenon. He famously noted that leadership was one of the most talked about and least understood subjects in both scholarship and everyday life. How can it best be understood? From the very beginning, in his Prologue to Leadership, Burns imagined a "general theory of political leadership." 12 Years later he led and mobilized a group of his professional colleagues to attempt to come up with such a general theory. Deliberations about that project began at the Jepson School in 2001 and continued at various venues for several years until a book edited by Burns's colleagues George Goethals and Georgia Sorenson, called The Quest for a General Theory of Leadership, was published in 2006. ${ }^{13}$ Although the quest ultimately failed, the work that came from that effort showed the reach of Burns's contributions to our understanding of the moral, psychological, and political aspects of leadership. James MacGregor Burns's personal and conceptual urgings brought that work and many other projects to fulfillment. It is a legacy of enormous importance.

\section{THE CURRENT VOLUME}

The ten chapters here can be divided into two sections: one composed of works that both embrace and challenge some of James MacGregor Burns's conceptual claims; and the other comprising applications of Burns's most important concepts to understanding leadership in several historical contexts. The first set of chapters, grouped under the heading 
"James MacGregor Burns and the Essentials of Leadership," underlines the breadth and reach of Burns's ideas in that each of the five chapters is written by scholars in different disciplines whose fields Burns's work influenced. They are written by an historian, a political scientist, an organizational scholar, two psychologists, and a philosopher, in that order, and explore the origin of the idea of leadership, Burns's conception of causality, the possibilities of change, the psychological underpinnings of leading and following, and connections between the personal morality and public leadership of powerful leaders. The second set of chapters"James MacGregor Burns and American Leadership"-considers the US presidency in general and the specific presidencies of Thomas Jefferson, Franklin Roosevelt, John F. Kennedy, and Lyndon B. Johnson, as well as leadership in the early years of the American experiment. All five chapters in this section employ conceptual tools taken directly from Burns's theoretical analyzes of leadership.

\section{James MacGregor Burns and the Essentials of Leadership}

The first chapter in Part I, by Patrick Spero, "Discovering Leadership in the Early Republic," offers a fascinating look at the way in which the term leadership came into the American vocabulary; how leadership in the first years of the United States was understood; and how that understanding informed Professor Burns and other scholars of leadership. Much of Burns's work can be seen as developing that early conception of leadership.

In Chapter 2, "Leadership without Leaders, Followers, or Causality: Tribute and Tribulation for the Intellectual Legacy of James MacGregor Burns," Richard A. Couto argues that despite considerable modification of his earliest perspectives on leadership_-including the creation of a dichotomous typology of transactional and transforming leadershipBurns's later work fell short of the transforming paradigm required to align the everyday nature of leadership with the manner in which we study and talk about it. Those shortfalls include the lingering shadow of the leader-centrism that haunts Burns's work, the hierarchical distinction implied in leaders and followers, and the causality of leadership. To address them means studying leadership without leaders, without followers, and as a necessary but not sufficient condition of change.

Chapter 3, by Gill Robinson Hickman, "Real, Intended Change: Business Movements?," examines several new business movements in relation to Burns's concept of real, intended change. The chapter argues that new business forms, such as benefit corporations, may challenge the notion that business leaders cannot overcome organizational constraints 
and profit motives to meet Burns's social change imperative for real, intended change.

Chapter 4, by George R. Goethals and Scott T. Allison, "Transforming Motives and Mentors: The Heroic Leadership of James MacGregor Burns," suggests how a conversation with Jim Burns about human motivation might unfold today. Burns was very taken with Abraham Maslow's hierarchy of needs and the idea that the loftiest motivation, the need for self-actualization, might contribute to transforming leadership. This chapter suggests that the human need for meaning and significance might be the key to effective and moral leadership. It suggests, moreover, that human needs evolve over the lifespan and in response to changing circumstances, bringing about a corresponding shift in our preferences for transforming leaders.

In Chapter 5, "Dangerous Liaisons: Adultery and the Ethics of Presidential Leadership," Joanne B. Ciulla takes issue with Burns's contention that adultery does not affect presidential leadership. She explores differing philosophical perspectives on whether character and morality are singular and integrated or divisible into separate parts. She then describes the unethical behavior of presidents who had adulterous affairs, and the real and potential harms of their behavior to the presidency and the country. Ciulla's chapter reflects other debates she had with Burns about his use of the terms virtue, ethics, and values and how they obscured some of the connections between private and public morality in leaders.

\section{James MacGregor Burns and American Leadership}

Part II opens with Chapter 6, by Douglas Bradburn, "AA people unused to restraint must be led, they will not be drove': The Rebels and Their Leaders in the American Revolution," which considers the distinct qualities of transforming leadership in the Revolutionary era and the early American republic, and the form such leadership took for both leaders and followers. Bradburn examines the way leaders and followers constructed leadership together through the new institutions created during the rebellion against Great Britain. By recognizing that these institutions created leaders who were supposed to be responsive to the "people" (a people that George Washington considered "unused to restraint") we can begin to understand the advantage of leadership displayed by the Americans, and unmatched by the British.

Thomas E. Cronin's Chapter 7, "James MacGregor Burns and the American Presidency," explores Burns's evolving view of the inadequacies of the United States' eighteenth-century constitutional arrangements and 
the difficulties it creates for efforts at transforming presidential leadership. Burns increasingly lamented the lack of authority that constrains US presidents.

In Chapter 8, "Transactional Leadership in a Transformative Election: An Essay in Honor of James MacGregor Burns," Edward J. Larson explores the interplay of transactional and transforming leadership in the election of 1800, and the way Aaron Burr's transactions combined with Thomas Jefferson's transformative impact to produce a turning point in American political history. He compares their leadership with Roosevelt's stunning combination of transactional and transforming leadership as developed in his classic The Lion and the Fox.

Larson's chapter provides context for Susan Dunn's Chapter 9, "James MacGregor Burns's Roosevelt: The Lion and the Fox and the Election of 1940," again showing how transactional and transforming leadership can be skillfully combined by a singular leader. Dunn shows how, during the run-up to his nomination for a third term, the transforming FDR roared like a lion but the transactional FDR employed the devious designs of the fox in winning re-election.

The final chapter, Georgia Sorenson's "Theory and Practice: James MacGregor Burns," explores Burns's commitment to marrying theories of leadership to practical politics and how his studies of the presidencies of Roosevelt, Kennedy, and Lyndon B. Johnson influenced his understanding of leadership - and the way a good theory could be made useful in politics. Her chapter also gives insight into the way Burns's work sometimes influenced presidencies.

Finally, I am indebted to Thomas E. Cronin for a wonderful epilogue to this tribute to the legacy of James MacGregor Burns.

\section{NOTES}

1. James MacGregor Burns, Leadership (New York: Harper \& Row, 1978).

2. Burns, 1978, 18.

3. Burns, 1978, 18.

4. Bernard M. Bass, Leadership and Performance Beyond Expectations (New York: Free Press, 1985).

5. Burns, 1978, 20.

6. Burns, 1978, 40.

7. Sigmund Freud, New Introductory Lectures on Psycho-Analysis (New York: Norton, 1933), 112.

8. James MacGregor Burns, Transforming Leadership (New York: Atlantic Monthly Press, 2003), 2.

9. Burns, 2003, 28.

10. Burns, 1978, 461 (italics in original).

11. Burns, 2003, 168. 
12. Burns, 1978, 5 .

13. George R. Goethals and Georgia L.J. Sorenson, The Quest for a General Theory of Leadership (Cheltenham, UK and Northampton, MA, USA: Edward Elgar Publishing, 2006). 